\title{
A Study on the Applicability of Environmental Tax "Double Dividend" in China
}

\author{
Xiaohua Hou, Rui Du, Juan Huang, Lijuan Liu
}

Shaanxi Institute of International Trade \& Commerce, Xi'an City, Shaanxi Province, 712046, China

Keywords:Environmental tax; Double dividend; China; Applicability; Tax reform

\begin{abstract}
The "double dividend" theory of environmental taxes can provide the basis and direction for the reform of environmental taxes in China. For a long time, China's environmental related taxes are at a low level. Levying environmental taxes does not bring too much burden to enterprises and the public. At present, the most important purpose of levying environmental taxes in China is to curb the heavy pollution production and management activities, and to promote the adjustment of industrial structure and technological innovation through pressuring. Based on the current situation of China's environmental protection and the author's research results, this paper first analyzed the basic contents of "double dividend" of environmental tax, and then discussed the "double dividend" and China practice and significance, finally put forward the reform proposals of environmental tax in China based on the "double dividend" of environmental tax.
\end{abstract}

\section{Introduction}

From the beginning of 1990, the organization for economic cooperation and development (OECD) in some countries, such as Holland, Norway and Sweden have carried out different forms of environmental taxes (including some form of carbon tax), and they have achieved some experience and good results. However, the experience of OECD countries can not be copied completely. After all, the tax system in western countries does not coincide with China's national conditions. Domestic scholars also put forward their own views and opinions, and some also use empirical methods to demonstrate whether green tax reform can produce "double dividend". Therefore, this article will explain the basic idea of "double dividend", and discuss whether the "double dividend" exists in the current tax system, and then will discuss whether the environmental tax reform is feasible.

\section{The Basic Content of "Double Dividend" of Environmental Tax}

The basic meaning of "double dividend" of environmental tax is that the levy of environmental tax can not only effectively curb pollution and improve the quality of ecological environment, but also achieve the goal of environmental protection; moreover, "double dividend" of environmental tax can also reduce the existing tax on capital using tax revenue and distorting effects produced by labour, which is conducive to social employment, economic growth, the implementation of "green dividend" and "blue dividend". According to the "double dividend" theory, environmental tax can control pollution behavior, so as to achieve the purpose of improving the environment. This is the so-called environmental tax first dividend. Second, environmental taxes usually increase government revenues, which the government can use to improve the quality of the environment or the fiscal structure of the government. When the environmental tax revenue is devoted to improve the quality of the environment outside the field, the environment tax revenue to reduce the system distortion existing in the economic system can bring more benefits, so as to make the society get a second bonus. In addition to the environmental tax, which is considered the most effective way to control environmental pollution, it is considered a better financial gain than traditional fiscal methods. Therefore, people usually think that the theory of "double dividend" is of epoch-making significance. 


\section{The Applicability of Environmental Tax "Double Dividend" in China}

The applicability of "growth double dividend" in China. Theoretically, environmental taxes provide market participants with more efficient allocation of resources and provide incentives to promote economic growth. However, environmental tax is not absolutely encouraging for enterprise innovation: on the one hand, environmental tax can stimulate enterprises to implement technological innovation, and realize the win-win situation of environmental protection and economic growth through the compensation mechanism; on the other hand, the environmental tax increases the operating costs of enterprises and weakens the ability of enterprises to innovate. Therefore, environmental tax incentives for enterprise innovation are uncertain. Levying environmental protection tax in China has a great influence on the enterprises with high pollution emission in the short term. The tax compulsory and budget rigidity after the reform of the sewage charges will reduce the space for the enterprises to bargain on the tax expenses to a certain extent, so the production and operation costs of enterprises will increase. The introduction of environmental technology innovation by polluting enterprises is often at a disadvantage in the short run compared with traditional enterprises, which may affect the initiative of enterprise technological innovation. However, the environmental tax policy has the function of stimulating enterprises to carry out incremental innovation. If the continuous environmental tax policy design takes full account of the industry characteristics, technical conditions and tax rate design, it will play an important role in green economic growth. Especially when alternative environmental innovation technologies are mature,the government will appropriately raise the environmental tax rate (tax rate is too low to easily cause the enterprise to buypollution) complemented by market mechanism and competition between enterprises, which can promote the enterprise initiative innovation. Therefore, in the long run, environmental taxes stimulate enterprise innovation and gain the first mover advantage, which naturally has a positive effect on economic growth.

The applicability of "double dividend of distribution" in China. The essence of environmental tax is to investigate the fair effect of environmental tax. A large number of western scholars have proved that environmental taxes are regressive. Most of the areas covered by environmental taxes are related to resources, energy, transportation, construction, paper making and so on. From the angle of tax burden transfer, they are regressive. Environmental taxes are closely related to the living costs of modern people, such as cold keeping, heating, electricity and transportation, etc., and their tax burden transfer is not beneficial to low-income families, but has little effect on high-income families. Energy expenditure is generally divided into transportation, energy and heat generating energy, and households with different income classes have little difference in heat production and energy consumption. However, there is a big difference in transportation and energy expenditure; the environmental tax on traffic energy is slightly progressive, which has a strong regressive effect on heat generating energy and environmental taxes. Therefore, the environmental tax levied on energy sources shows a tendency to be regressive. The experience of European Union countries is that environmental taxes are levied to reduce income taxes or return taxes on low-income families. Considering the special personal income tax and social security system in China, it is not easy to realize "income distribution dividend". Based on the fairness of tax burden and the need for structural tax cuts, China can reduce or eliminate the regressive tendency in environmental tax through two aspects: the first is the overall design for the structural tax cuts; while levying environmental taxes, we should reduce other distortions to enhance the overall tax system; second, we enhance their tax progression through differentiated design of the environmental tax and tax elements (such as tax rates, tax incentives).

Applicability of "double dividend of employment" in China. China and western countries have different tax system structure and collection and management level. It is difficult to reduce the labor related taxes and raise the income after tax through environmental taxes, which is due to the special personal income tax in China. According to 2016 data released by the ministry of finance, the number of individual income tax in China is accounted for only about $2 \%$, and the proportion of the share of personal income tax in the total tax revenue is only about $8 \%$ with a large number of low-income people who do not pay personal income tax. In other words, the "income cycle effect" 
(positive effect) brought about by reducing the income tax tax with environmental tax income will be difficult to achieve in the short term. Further, the environmental protection tax of China is similar to a kind of translation of sewage charges. The tax burden of enterprises will fluctuate in the short term. The operating cost may increase, but it will not change much. Therefore, the tax effects (negative effects) brought about by the taxation of pollution products and the increase in consumer prices are not particularly evident. Therefore, there is a great deal of uncertainty about the acquisition of "double dividend of employment". However, the introduction of environmental taxes by the government can guide enterprises to produce more labor-intensive products, and reduce the production of pollution intensive products, and ultimately create a potential "double dividend of employment". With the strengthening of environmental protection, the adjustment of economic structure and the improvement of tax structure, the government pays attention to the development of low-carbon economy, so green employment is likely to become a major direction of changes in the structure of employment in the future.

\section{The Suggestion of Environmental Tax Reform in Chinabased on the Environmental Tax "Double Dividend"}

For a long time, China's environmental taxation fees are at a low leveland China's tax revenue accounted for the proportion of national income in recent years also showed a downward trend, so the introduction of environmental taxes will notbring too much burden of enterprises and the public. In particular, China has introduced a new tax policy, and increased the personal income tax threshold into $3500 \mathrm{RMB}$. In addition to alleviating the rich and poor gap, balancing the tax burden, stimulating consumption and other benign effects, it has laid a good foundation for levying environmental taxes. It weakens the burdens imposed by environmental taxes on businesses and the public.

The income tax in the west is the most important part of the tax system, so they take full account of the distortion of income tax when making environmental taxes. In China, value-added tax is the main body, and the proportion of personal income tax in the tax is still relatively low. China has not levied social security tax, so the "double dividend of employment" may not be well reflected in China. The research shows that the environmental tax revenue will be inverted "U" structure over time, which coincides with the impact of VAT transformation on tax revenue; to a certain extent, it slows down the oscillation of tax revenue in tax reform. Therefore, according to China's economic environment with considering the indirect tax such as value-added tax and the distortion of social resources allocation, the implementation of environmental tax will make it possible to obtain the "double dividend" of environmental taxes.

For China, the most important purpose of levying environmental tax is to restrain the production and operation of heavy pollution to a certain extent. We will promote the adjustment of industrial structure and promote technological innovation through pressure. The levy of environmental taxes should be "earmarking", and the state should make investment in such areas as regulation and control so as to help the reform of polluting enterprises. Therefore, as for the the introduction of environmental taxes, the first consideration is not the increase of state revenue, which should be considered the question about how to realize the environmental protection and industrial restructuring and technological progress based on cost of the implementation of environmental policy.

\section{Summary}

At present, there are many arguments about "double dividend" in academic circles, mainly focusing on the realization of "double dividend". If the theoretical conditions for the realization of the "double dividend" do not exist in reality, then the effect of environmental tax in concrete implementation remains to be further explored. The study of "double dividend" has always been based on foreign countries, while China's situation has its particularity, so the implementation of environmental taxes remains to be further explored. 


\section{Acknowledgement}

Project Source: Shaanxi Provincial Science and Technology Department,funding

Project Name: This work is supported by the Shaanxi Province,the new situation of financial security research: monitoring and early warning

Project Number: 2013JM9004.

\section{References}

[1] Wang Xinbo, Pan Enyang, Ma Dongchun. A Study on the Existence of Double Dividend in Environmental Taxation[J]. Ecology and Economics, 2014, (07): 37-42.

[2]Chen Feng, Cheng Huiqiang, Zhang Liangyue. The Choice of China's Environmental Tax Reform Path: Based on the Double Dividend of Environmental Tax[J]. Taxation and Economics, 2013, (05): 84-89.

[3] Liang Wei, Zhang Huiying, Jiang Wei. The Environmental Tax "Double Dividend Hypothesis -Based on the Local Tax Inspection and Analysis from the Perspective of [J/OL]. Finance Research, 2013, (04): 110-117+125.

[4] Yu Jie. Double Dividend of Environmental Tax and the Orientation of Environmental Tax Reform in China.[J]. Macroeconomic Research, 2013, (08): 3-7+17.

[5] Cao Jianxin, Huang Erni. Discussion on Environmental Tax Reform in China Based on Double Dividend Theory[J]. Business Accounting, 2012, (19): 12-14.

[6] Wang Hui. Is the Double Dividend of Environmental Taxes Really Possible?[J]. Contemporary Finance, 2011, (04): 46-54.

[7]Lan Xiangjie. Double Dividend Theory of Environmental Tax and Its Enlightenment to Contemporary[J]. Finance, 2010, (09): 29-33. 